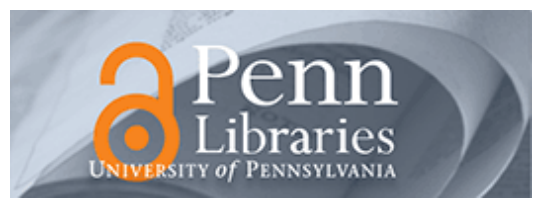

University of Pennsylvania

ScholarlyCommons

\title{
Education by Corporation: The Merits and Perils of For-Profit Higher Education for a Democratic Citizenry
}

\author{
Amy J. Sepinwall \\ University of Pennsylvania, sepin@wharton.upenn.edu
}

Follow this and additional works at: https://repository.upenn.edu/lgst_papers

Part of the Business Law, Public Responsibility, and Ethics Commons, Education Economics

Commons, Higher Education Commons, Higher Education Administration Commons, Law Commons, Nonprofit Administration and Management Commons, and the Organizational Behavior and Theory Commons

\section{Recommended Citation (OVERRIDE)}

Sepinwall, A.J. (2014). Education by Corporation: The Merits and Perils of For-Profit Higher Education for a Democratic Citizenry. In Urban, G. (Ed.), Corporations and Citizenship, 88-106. University of Pennsylvania Press.

This paper is posted at ScholarlyCommons. https://repository.upenn.edu/lgst_papers/59

For more information, please contact repository@pobox.upenn.edu. 


\title{
Education by Corporation: The Merits and Perils of For-Profit Higher Education for a Democratic Citizenry
}

\author{
Abstract \\ For-profit colleges have elicited wildly divergent reactions, with critics vilifying them and their executives, \\ and supporters seeing in the institutions a necessary and laudable complement to public and nonprofit \\ institutions. As I propose in this chapter, the truth likely lies somewhere between these extremes. \\ Disciplines \\ Business Law, Public Responsibility, and Ethics | Education Economics | Higher Education | Higher \\ Education Administration | Law | Nonprofit Administration and Management | Organizational Behavior and \\ Theory
}




\title{
Education by Corporation
}

\section{The Merits and Perils of For-Profit Higher Education for a Democratic Citizenry}

\author{
Amy J. Sepinwall
}

For-profit colleges have elicited wildly divergent reactions, with critics vilifying them and their executives, and supporters seeing in the institutions a necessary and laudable complement to public and nonprofit institutions. As I propose in this chapter, the truth likely likes somewhere between these extremes.

The for-profit educational sector has become an increasingly prominent and powerful presence within higher education. For-profit (FP) colleges have seen an average rate of growth of 9 percent per year, over each of the past thirty years. ${ }^{1}$ Today FPs educate roughly 1.4 million postsecondary students in the United States, accounting for 7 percent of all postsecondary students. The largest FP college system-the University of Phoenix-enrolls more students than do all of the Big Ten schools together, and is second in student population only to the State University of New York. ${ }^{2}$

The growth of FPs can be gleaned not just from increasing student enrollments over time, but also from increasing revenues. Thus, for example, the for-profit sector generated $\$ 9$ billion in revenue in 2000 , but $\$ 29.2$ billion in $2010 ;{ }^{3}$ most of this was earned by thirteen large, publicly traded companies that dominate the for-profit higher education market. ${ }^{4}$ The sector has attracted the attention of both venture capitalists and large institutional inves- 
tors, who see an unprecedented opportunity in the confluence of new technologies and interest in nontraditional educational platforms. ${ }^{5}$

While the public imagination casts the FP educational institution as brutishly profit-oriented, and its not-for-profit (NFP) counterpart as highmindedly unconcerned with revenues, the distinction between the two on this front is not so stark. NFPs need to be concerned about generating enough revenue to fund their activities. To this end, they often pursue profit-making activities - most obviously by fundraising and applying for grants, but also by securing patents for university-created products or technologies from which they can yield royalty fees, or by offering expensive degree or certificate programs for which the university does not extend financial aid. ${ }^{6}$ The key distinction between the FP and NFP entity, then, pertains not to whether the entity is permitted to earn revenue that exceeds operating costs but instead to what the entity may do with this surplus. In particular, the NFP must reinvest any surplus in the institution, whereas the FP institution is permitted to distribute the surplus to its owners or shareholders.?

The key source of revenue for FPs is student tuition. These institutions tend to cost less than private NFPs, but more than public colleges or universities. In 2010-2011, for example-the most recent year for which national figures are available - the average cost at a public university for in-state students living on campus was $\$ 20,100$, while the average cost for a four-year nonprofit college was $\$ 39,800$ and $\$ 30,100$ for a for-profit college. (Community colleges, the cheapest options, averaged $\$ 7,900$. ${ }^{8}$ The FP's reliance on student tuition, in addition to the profit-making imperative that the FP institution owes its investors, accounts for many of the FP's worst abuses.

This chapter incorporates considerations raised in the context of a panel discussion held at the University of Pennsylvania featuring three leaders in the for-profit education world. ${ }^{9}$ I propose here to amplify the conversation with reference to the existing literature on for-profit higher education. Commentary on for-profit education proceeds along three narratives: the first views the for-profit college as a kind of villainous, unstoppable monster; the second, contrastingly, sees the for-profit college as a kind of savior; and the third takes a more nuanced position, identifying virtues of for-profit education while expressing concern about its compatibility with education's traditional democratic aims. I present and critique each of these narratives in turn. 


\section{For-Profits as Villains}

Education, including higher education, is often seen as sacred-above base concerns about making money, and crucial to the advancement of the individual and the society to which she belongs. To the extent that for-profit institutions problematize, if not pervert, this vision, these institutions are cast as enemies of the public good. Thus one critic likens the FP higher education sector to "the blob,"10 threatening to swallow and replace traditional institutions, and another refers to the University of Phoenix in particular as "the anti-Christ."11

Some of this criticism is fueled by those cases in which a for-profit college has willfully engaged in acts of deception or fraud. But for other critics, forprofit higher education is inherently repellent, even if not out-and-out criminal, since the quest for profits is, they contend, necessarily in tension with educational quality. In its worst manifestation, the profit motive entails exploitation of the students whom these institutions target. But even when the institution's conduct does not rise to the level of exploitation, the for-profit college is nonetheless alleged to shortchange those it is intended to serve, by privileging owners or shareholders over its student-consumers. I elaborate on each of these concerns in turn.

\section{For-Profit Colleges and Illegal Activity}

FP colleges have been charged with two kinds of statutory violation. First, some have offered incentive-based compensation to recruiters, keyed to the number of students the recruiters succeed in enrolling, in contravention of the Higher Education Act, which forbids this kind of compensation to entities receiving federal funds. For example, in 2004, the government sued the Apollo Group, parent company of the University of Phoenix, for its alleged pay-forperformance recruitment incentives. The company denied wrongdoing but nonetheless settled with the government for $\$ 78.5$ million, believed to be one of the largest pay-for-performance compensation settlements ever reached. ${ }^{12}$

Second, many FP colleges have been found to have engaged in fraudulent or deceptive marketing practices. In 2010, for example, the Government Accounting Office released a report based on an undercover investigation of fifteen FP colleges. The colleges in question were selected only because they received at least 89 percent of their funding from the federal government; prior to the investigation, there was nothing about the colleges that had alerted the GAO to any wrongdoing. Nonetheless, the GAO discovered that 
all fifteen misled prospective applicants about the cost or value of the education they would receive. For example, recruiters commonly stated that students attend classes twelve months a year yet reported the tuition costs for just nine months of classes, thereby misleading the potential recruit about the full cost of tuition. ${ }^{13}$ In one instance, a recruiter told a prospective student that the massage therapy certificate program about which she was inquiring was a good value at $\$ 14,000$ in tuition, yet a nearby community college offered the same certificate program for just $\$ 520 .{ }^{14}$ Worse still, four of the fifteen colleges encouraged prospective students to lie on their financial aid application forms - in one case urging the applicant to omit information about $\$ 250,000$ that he had in savings, ${ }^{15}$ and in another advising the applicant to fabricate three dependents in order to appear more needy. ${ }^{16}$

These examples involve clear ethical and legal breaches. Nonetheless, a few bad apples do not make for a bad tree: it is easy to see how the profit motive might make such breaches more likely, but there is nothing in the for-profit structure that renders fraud or deception necessary or inevitable. The merits of FP higher education cannot be decided on the basis of these lapses alone. However, if it turned out that the FP college's quest for profits entailed widespread abuses-whether the ones just detailed or instead efforts to exploit prospective students' vulnerabilities, or sacrifice the quality of their education for the sake of lining shareholders' pockets-we would then have more reason for concern. And indeed, FP colleges have been charged with just such abuses.

\section{For-Profit Colleges and Exploitation}

Tales of FPs' predatory recruitment practices abound. The University of Phoenix and Chancellor's School of Professional Studies, both for-profit institutions, have targeted homeless shelters and halfway houses for potential students, seeking to enroll individuals who are recovering drug addicts or alcoholics, or convicted felons. ${ }^{17}$ Recruiters have also sought to prey upon minorities and other members of historically oppressed groups, ${ }^{18}$ and they have been especially keen to pursue military veterans, since veterans enjoy federal education benefits that do not count toward the 90 percent cap on federal funds imposed upon FP institutions. ${ }^{19}$

Recruiters are alleged to overstate the economic benefits of the degrees their institutions offer, and to minimize or fail altogether to disclose the difficulties in repaying loans that their students face: ${ }^{20}$ many more students at for-profit institutions than at not-for-profit institutions carry federal loans86 versus 63 percent. ${ }^{21}$ And, while students at for-profit universities compose 
just 10 percent of all college students in the United States, they represent 44 percent of those who default on their federal college loans. Critics attribute the higher default rate to a greater rate of attrition at FPs-the graduation rates there are 28 percent, compared with 65 percent at NFPs. ${ }^{22}$ The low graduation rates result, in turn, from the poor instructional quality and lack of support that FPs provide, critics contend. Yet even those who do graduate from FP colleges default more often than their NFP graduating counterparts, a disparity that critics attribute to the (purported) worthlessness of a degree from a FP institution. ${ }^{23}$

Because of these alleged abuses, Senator Tom Harkin, D-Illinois and chair of the Senate Health, Education, Labor, and Pensions Committee, sought to investigate the for-profit higher education sector. The investigation culminated in a report, issued in August 2012, that contained, in Harkin's words, "overwhelming documentation of exorbitant tuition, aggressive recruiting practices, abysmal student outcomes, taxpayer dollars spent on marketing and pocketed as profit, and regulatory evasion and manipulation." ${ }^{4}$

To the extent these abuses exist, they have been likened to the free riding and moral hazard that precipitated the housing market crisis. As Amitai Etzioni quips, FPs "are making money not by producing a product and marketing it, but by loading consumers with loans they cannot pay and then sticking the taxpayers with the bill. Only this time, it's not houses and mortgages but 'higher' education and student loans." 25 One former admissions officer grew so disenchanted with the aggressive recruitment strategies he was expected to pursue that he decided to dramatize his experiences in a one-act play called For Profit, which toured the United States in $2012 .{ }^{26}$ In an interview, the playwright, Aaron Calafato, recounts that he was being pushed to enroll single mothers, recovering addicts, and others who had barely earned their high school equivalency diplomas, or could barely read-and all would come to carry heavy student loans. ${ }^{27}$

Far from enhancing the financial prospects of the members of these vulnerable groups, it is clear that saddling them with loans that they will be unable to pay off imposes yet another obstacle on their paths to prosperity. But these unseemly and exploitative recruitment practices are not a necessary part of the for-profit landscape. Like the illegal activity detailed above, the predatory practices of some for-profit educational institutions ought not to impugn the industry as a whole. We can readily imagine a for-profit college that engages in a stringent vetting and admissions process, selecting only those students who show the requisite promise, and who are made aware of the burdens 
that college studies impose. Along these lines, Kaplan Higher Education allows students to try out its college programs for three weeks, free of cost and with no record of matriculation should the student choose to leave after the trial period. In this way, prospective students are given the opportunity to see firsthand whether they can handle the work. ${ }^{28}$ Similarly, there are FP colleges that have developed a solid track record of placing their graduates in wellpaying, secure jobs. ${ }^{29}$ Further, in addition to self-restraint, we can turn to government regulation to minimize opportunities for predation, through mandated disclosures to prospective students. Such initiatives are already under way. For example, the U.S. Department of Education has proposed tougher rules forbidding colleges from paying recruiters on commission..$^{30}$ And, a recently issued Executive Order on recruitment of veterans also seeks to reduce their exploitation. ${ }^{31}$

Given the fact that FPs rely far more on tuition as a source of revenue than do public and NFP institutions, exploitative recruitment practices may be more common in the for-profit sector. But again, there is nothing about forprofit education that requires these practices. In any event, even if self-restraint or governmental regulation were to curtail these practices, there might still remain concerns with for-profit higher education, as we shall now see.

\section{For-Profit Colleges and Shareholder Primacy}

FP colleges need not resort to illegal or exploitative conduct in order to invite the suspicion that there is something untoward about their business model. For one thing, many people tend to view money-making as antithetical to the intellectual pursuits that we take to typify a university education. I defer consideration of such concerns to a subsequent section, where I address the question of whether FP higher education illicitly commodifies a good that should be beyond market value. Here, I consider whether the premium FPs place on generating financial returns for shareholders negatively affects the quality of the education they provide.

The traditional view of the for-profit corporation grants pride of place to the corporate shareholder: the purpose of the corporation, in this view-often called the shareholder primacy view-is to earn money for shareholders. Measures that benefit constituencies other than shareholders-employees, consumers (e.g., students of the FP college), society at large, and so on-are to be pursued only if, and to the extent that, they redound ultimately to the benefit of shareholders. Correspondingly, initiatives that would diminish shareholder returns are to be avoided. 
Because of the near-hegemony the shareholder primacy norm enjoys, critics of FP higher education are led to believe that the FP institution will sacrifice student welfare whenever doing otherwise would lead to a loss of potential shareholder or managerial profits. ${ }^{32}$ Thus, for example, David W. Breneman, dean of the Curry School of Education at the University of Virginia, contends that "Wall Street has put [FP colleges] under inordinate pressure to keep up the profits, and my take on it is that they succumbed to that." ${ }^{33}$ Prominent educators, students, and some of the University of Phoenix's own former administrators say the relentless pressure for higher profits has diminished academic quality ${ }^{34}$-for example, by propelling FP institutions to hire less experienced teachers, who do not command as high a salary, or deny admission to special needs students given the additional costs of accommodating them. ${ }^{35}$

Further, in addition to engaging in morally dubious cost-cutting measures, there is a concern that the FP college might incur expenditures that divert resources away from the students it does enroll. For example, given the extent to which FP colleges rely on student tuition for revenue, these colleges spend vast sums on marketing and advertising. Thus, the Apollo Group, which owns the University of Phoenix, spends roughly 20 percent of its revenue on "selling and promotional" expenses. ${ }^{36}$ And according to the Harkin report invoked above, the investigated colleges had ten times as many recruiters as career-services staff members-32,496 and 3,512, respectivelysuggesting that these institutions are more intent on taking in tuition funds than training and placing their students. ${ }^{37}$ In contrast, FP advocates point out that the traditional sector is not without its own marketing imperatives. As Peter Smith quips, athletic directors at public and nonprofit institutions have to sell their schools to potential recruits too. ${ }^{38}$ And outreach efforts can benefit members of underserved communities that might not otherwise have the wherewithal or resources to access information about higher educational opportunities. ${ }^{39}$

More generally, FP advocates reject a zero-sum view of the FP entity, according to which shareholder gains necessitate reductions in educational quality. Instead, at least some see student satisfaction and success as a key to shareholder wealth. Thus some FP advocates insist that at their institutions students absolutely come first-and they contrast this priority with the reigning hierarchy at traditional institutions, which, these advocates maintain, tend to indulge and pander to the often prima donna-like attitudes of their faculty. $^{40}$ 
To the extent that shareholder primacy entails that the firm maximize shareholder returns, the concern about the for-profit form has traction; a norm of shareholder maximization would entail that the firm pursue whatever initiatives benefit shareholders most, and it stands to reason that shareholder value can sometimes be maximized only by sacrificing some amount of educational quality. For example, seniority pay and tenure help to retain better and more experienced faculty, but increase costs and thereby diminish shareholder profits; similarly, a well-stocked library, landscaped grounds, and state-of-the-art computer labs and athletic facilities can all enhance the quality of the student's experience, but these too increase costs at shareholders' expense.

By contrast, a norm of shareholder primacy need not be so demanding; so long as the firm attends to and seeks to augment shareholder value, it has satisfied the norm. And it can do so consistent with sometimes foregoing more profitable opportunities, in order to ensure that its students receive a good-quality education. Nor does the law mandate maximization of shareholder value. Instead, prominent statements of law permit corporate officers to pursue ethical objectives even if doing so fails to enhance shareholder value at all. ${ }^{41}$ To be sure, the corporation will fail to attract and retain investors if it does little or nothing to seek to turn a profit. But the quest for profit need not operate to the exclusion of the quest for quality.

The question, then, is not whether the FP college can afford to provide adequate quality, but instead whether it can provide an education or degree equal or superior in value to that provided by traditional colleges. Does the FP college have unique capacities or competencies that should cause us to welcome its presence on the higher education scene?

\section{For-Profit Colleges as Saviors}

In 2009, President Barack Obama called for a doubling of the number of college graduates in the United States by the year 2020. ${ }^{42}$ For-profit advocates contend that public and NFP universities cannot meet that goal alone. In particular, only by enrolling nontraditional students could the country increase the number of degree holders so significantly. ${ }^{43}$ Enter the FP college.

Yet the FP's aspired role is even loftier than that. The supporter of FP education aims not only to award college degrees to more people but in particular to recruit individuals who have historically, and in some cases 
systematically, been excluded from traditional colleges, and to rescue them from their positions of relative disadvantage with the leg-up that a college degree provides. As one FP entrepreneur put it, the industry wants "to put 'the flying car of higher education in the driveway of every student.' "44 In this way, champions and purveyors of FP higher education operate with a nearmessianic vision.

More specifically, supporters of FP institutions believe that these institutions are uniquely placed to serve the needs of traditionally underrepresented students. Thus, these supporters highlight the FP college's ability to accommodate the needs and schedules of nontraditional college students. For example, whereas traditional colleges undertake lengthy admissions processes and have students matriculate at just a handful of fixed times over the course of the school year, FPs boast that they return prospective students' requests for information within fifteen minutes, and can have the student begin courses within a month of the call. ${ }^{45}$ The FP colleges schedule courses in four-hour blocks, running from 8:00 a.m. to 10:00 p.m., which makes it easier for students to combine a full-time job with their studies. ${ }^{46}$ Many also offer courses online, which students can pursue on their own time, thereby further accommodating students' work lives. ${ }^{47}$

FPs provide flexibility not just in terms of scheduling but in terms of course offerings as well. Unlike their traditional counterparts, FPs can readily add classes or programs in response to changing demand. This greater responsiveness results in no small part from the FPs' governance structure-typically centralized at corporate headquarters and uniform across campuses, unlike at traditional universities, where, for example, curriculum changes must be approved by faculty and can therefore take months if not years. ${ }^{48}$

More generally, supporters of FP colleges note that market-based competition can motivate for-profit entities to deliver better quality at a smaller cost. ${ }^{49} \mathrm{FP}$ institutions also have incentives to innovate, and their innovations can permeate the public domain or else motivate public institutions to produce innovations of their own, so as to compete. And FPs seem better able to make constructive use of new technologies than their traditional peers, as can be seen, for example, in the case of massive open online courses (MOOCs). These courses, typically taught by all-star professors at elite institutions, have the power to vastly improve the educational quality at FPs by allowing their students access to excellent instruction in courses rigorous enough to meet recognized accreditation standards. By contrast, MOOCs threaten to worsen the educational experience at a traditional institution, by eliminating intellec- 
tual diversity and rendering live instruction obsolete. Thus, for example, San Jose State University invited pushback when it proposed that its philosophy department replace some of their traditional ethics offerings with an online course entitled "Justice" taught by Harvard professor Michael Sandel. "The thought of the exact same social justice course being taught in various philosophy depts. across the country is downright scary," the philosophy department wrote in an open letter objecting to the initiative. In a similar vein, Amherst College's faculty voted against their school's producing MOOCs out of concern that MOOCs threatened to impose too much uniformity and centralization on higher education. Diversity is the welcome corollary of the intellectual freedom that pervades the traditional higher educational institution. As one commentator has put it, "When three great scholars teach a poem in three ways, it isn't inefficiency. It is the premise on which all humanistic inquiry is based." ${ }^{50}$ But FP higher education, for good or ill, is founded on a franchise model. If calculus 101, or poetry or ethics 101 for that matter, is to be taught in the same way to all of the FP institution's students no matter what, it is best that the instructor and course content be drawn from the top ranks of the traditional institutions.

In sum, FP colleges promise benefits that traditional institutions currently fail to provide, and may even be structurally incapable of providing. The consumer orientation of the FP institution may in principle increase traditionally disadvantaged groups' access to higher education, and thereby enhance their socioeconomic status. And the centralized governance structure and market incentives of the FP sector may create more dynamic and innovative institutions. At the same time, through the use of MOOCs, FPs may be able to offer their students the star power and quality instruction that elite institutions provide, without shortchanging their students by denying them the spontaneous and sometimes unique experiences emerging in the live classroom, since the FP was never going to offer its students those experiences in the first place.

What this means is that, in theory, there may be much to celebrate about the ideal FP college. Unfortunately, however, the reality may look far different from the ideal. The promise of FP colleges, and the self-congratulatory market rhetoric of which it is a part, depends upon ideal market conditions that may not and, in some instances, do not obtain. For one thing, champions of the free market assume no information asymmetries between suppliers and consumers. But it is notoriously difficult for prospective students to weigh the value and costs of particular higher education programs. ${ }^{51}$ It is for this reason 
that Congress is currently contemplating legislation that would require all colleges to provide financial aid applicants with a "shopping sheet." ${ }^{2}$ And to the extent that competition itself motivates greater transparency, so that consumers can compare options, there arises a concern that the competing institutions will privilege quantitative indicators of success, thereby neglecting or deemphasizing softer but no less significant attributes. ${ }^{53}$ The dramatically increased importance of standardized test scores provides evidence of this concern. $^{54}$

A second reason to be skeptical about the adduced benefits of market competition arises in light of the possibility that the requisite competition is absent: where the market is dominated by one entity, or supply is otherwise limited, the entity (or few entities) in question has fewer incentives to cater to its consumers. Students cannot readily transition between colleges: each institution may have different requirements for admission, or each may decline to award credit for courses completed elsewhere, or particular financial aid packages may not be transferable between institutions, or there may be only one game in town and the costs of moving elsewhere may be prohibitive. In short, exit is not a viable option for many. ${ }^{55}$

In any event, concerns about the fairness of the market are just one piece of the puzzle; there is a more foundational issue-namely, whether there should be a market in this arena at all. Thus, even were perfect market conditions to obtain, and even if FP colleges were genuinely and robustly consumer oriented, there would remain a question about the propriety of the market dynamic. For it may be that consumer satisfaction ought not to be an ultimate aim, let alone the ultimate aim, of higher education. No one doubts that individual welfare gains constitute one worthy goal of a college education. But higher education has traditionally conferred benefits on society as a whole, both economic and political, and these may be threatened by the increasing presence of FP colleges.

\section{For-Profit Colleges and the Public Good}

For-profit institutions boast that they can provide students with better job training than their traditional counterparts. "You don't go to one of our schools to be a classics major," the president of the Career College Association quips; their schools excel instead, he maintains, in conferring upon students skills "related to a real job in the real world." ${ }^{6}$ This difference in educational 
focus invites questions about what the goal of higher education should be and, indeed, whether the higher education landscape can accommodate diverse visions and aims, with some institutions more practically oriented and others furnishing a more traditional liberal arts education.

It is undoubtedly true that the workforce needs individuals who have received highly specialized training - in culinary arts, medical and lab technology, computer programming, and so on ${ }^{57}$ But the concern is that students, as members of a democratic populace, should also be exposed to a particular canon of subjects, and trained in particular modes of critical thinking. Some maintain that a college degree-unlike a proficiency certificate-implies just this kind of training, and that institutions that fail to provide it should not be permitted to confer the degree. Further, we might also worry that education is too lofty or sacred an arena to be governed by market forces; the notion that disinterested investors may earn a buck off the backs of students threatens to taint higher learning not because (or just because) FP colleges will have an incentive to pander but because money-making seems to be fundamentally at odds with higher education's foundational premises. I address each concern in turn..$^{58}$

\section{Higher Education as a Public Good}

From the time of the nation's founding, higher education has been seen as a critical public good, developing students who could go on to serve the public as a result of the training they had received. ${ }^{59}$ Thus, for example, the Continental Congress insisted that some portion of land in the Northwest Territories be reserved for public institutions of higher learning. ${ }^{60}$ Further, at least two delegates to the Federal Convention of 1787 advocated for the federal government's power to establish a college at the national level. ${ }^{61}$ Their cries were echoed by the first six presidents of the United States, each of whom beseeched Congress to establish a national public university. Contemporaneously, several state constitutions provided for the establishment of public universities within the state in question. ${ }^{62}$

The Founders, and their political successors, were committed to higher education because they saw in it "an extra-constitutional mechanism to preserve the republic by broadening the diffusion of learning across social classes and enlarging the population of persons possessing the skills required for democratic governance and useful in diversifying the economy." ${ }^{63}$ In this regard, it is worth noting that the American Association of University Professors, from the time of its formation in 1915 through to the present day, has in 
its successive articulations of its Declaration of Principles envisioned the university as a "public trust," given the role of "education [as] the cornerstone of the structure of society." ${ }^{64}$ And the Campus Compact, an association of the presidents of more than 1,100 public and private universities, has issued and reaffirmed a Declaration challenging "higher education to re-examine its public purposes and its commitments to the democratic ideal." 65

To be sure, a college degree confers upon the graduate a set of personal benefits-for example, it formally certifies that the degree holder has completed a particular course of study, it inducts the degree holder into a network of alumni who may function as useful personal and professional contacts, and it tends to allow the degree holder to earn more money than she would have earned without it. But higher education also enhances individuals' preparation for the duties and activities of citizenship. Those with college degrees are more likely to vote, and exhibit a greater interest in civic and political issues, even controlling for social background and personality traits. ${ }^{66}$ Collegeeducated citizens also display more social awareness, more political activism, and more humanitarianism. ${ }^{67}$ And society benefits from these outcomes as well, as greater numbers of college graduates generate increased charitable giving, lower public health costs, and a more diverse set of leaders. ${ }^{68}$

Education, like health care, is, for all these reasons, taken to be a prerequisite for both fulfilling one's life plan, and creating and preserving a wellfunctioning democracy. ${ }^{69}$ Further, the more educated the populace, the greater the nation-state's global standing. Even Milton Friedman, who advocated a market-based approach to education through vouchers, argued that a "stable and democratic society is impossible without widespread acceptance of some common set of values and without a minimum degree of literacy and knowledge on the part of most citizens." ${ }^{70}$ Or, to put the point even more succinctly, as Martha Nussbaum does in her bid to preserve a place for the humanities in higher education, "Without support from suitably educated citizens, no democracy can remain stable."71

FP institutions undercut a connection between higher education and democracy by neglecting to prepare students for citizenship. As a dean at one FP college unabashedly stated, "For-profit universities do not have as their primary mission the shaping of a more informed citizenry, or creating a more cultured population, or helping young people understand their heritage, their society, and its values." ${ }^{72}$ And it is not just that at least some FP institutions fail to enhance their students' civic engagement; they may even worsen it in some regards. In particular, an exclusive focus on educating for specific professional 
or vocational ends-what Martha Nussbaum calls "educating for profit"denies college students the opportunity to acquire or refine the rhetorical and critical thinking skills that democratic engagement requires. ${ }^{73}$ And the consumer satisfaction model might encourage or further entrench existing class, ethnic, and racial divides, as students vote with their feet in selecting institutions close to their already segregated neighborhoods, or whose student bodies consist largely of other students like them, thereby insulating themselves from a more diverse student body that could improve cross-class and crosscultural understanding. As Martha Minow writes, "Without regulation, more choice-including private religious options, for-profit options, and alternatives serving specialized interests-could produce self-segregation along the fault lines of race, class, gender, religion, disability, and national origin. As a result, schools could exacerbate misunderstandings among groups and impede the goal of building sufficient shared points of reference and aspirations for a diverse society to forge common bonds." ${ }^{\prime 4}$ Elizabeth Anderson echoes the worry when she insists not only that public leaders "must be drawn from all sectors of society, including the less advantaged" but also that "these diverse members must be educated together, so that they can develop competence in respectful intergroup interaction." 75

For these reasons, it is perhaps no wonder that "research suggests that students in the for-profit sector are less likely than students at nonprofit community colleges to vote, participate in political activities, or become involved in their communities." ${ }^{\prime 6}$ To the extent that this is true, the loss is not society's alone. The relative lack of civic engagement threatens to undermine the promise of providing upward mobility for the underprivileged student that the FP college holds out in justifying its existence. For that mobility results not just from the enhanced material benefits that a college degree can confer but also from participation in public life with an eye to eradicating other kinds of structural barriers currently impeding the underprivilegeds' success.

And beyond the substantive ways in which FP colleges might deny their students the democratic training that students at traditional colleges receive, there is a further worry that FP education threatens the very ethos of democratic citizenship. As one commentator has evocatively stated in the context of K-12 school choice, "The struggle is not between market-based reforms and the educational status quo. It is about whether the democratic ideal of the common good can survive the onslaught of a market mentality that threatens to turn every human relationship into a commercial transaction." ${ }^{77}$ The con- 
cern loses no force when what is contemplated is higher education rather than primary and secondary schooling.

\section{Commodification}

Worries about the incursion of a market discourse and rationale into the realm of education take many guises. For one thing, there is a general unease in subjecting something as (purportedly) lofty as education-especially higher education - to the base cost-benefit calculations that govern the market. $^{78}$ Further, delegation of a traditionally public function to a private entity, or the use of public dollars to fund a private entity, raises fears about a loss of public control and trust. The private school need not be responsive to the public will in the way that the public institution must be. To be sure, this concern arises for both FP and NFP colleges, but the former occasions it to a greater degree, since the FP college may be subject to fewer government constraints and since it affirmatively has obligations to a constituency other than its students or the public at large-that is, its shareholders. "Public control and review - whether through administrative or political processes-diminish as previously public activities fall under private management and control." 79 And the consequences of the delegation might extend beyond a sense that the FP institution may proceed with indifference to the public will; delegation may undermine public trust more generally. As Martha Minow notes, "The appearance of private motives in a public domain can undermine respect for government and even generate doubt whether the government is sincerely pursuing public purposes." ${ }^{\prime 0}$

More disturbing still, allowing for-profit entities to bridge the gap that traditional institutions have created obscures the fact that the public might bear responsibility for the gap in the first place. As Mark Rosenman writes, "Our elected leaders steadfastly refuse to generate the revenues government needs to do what needs to be done and instead favor an increasingly inequitable distribution of wealth ...; politicians cut the funding of cost-saving programs [like those that would keep students in school or improve their performance there] to come up with new avenues for capital to make private profit in meeting public needs." ${ }^{\prime 1}$ The incursion of profit-making entities into spheres traditionally occupied by the government undermines individual altruism, may lead to fewer charitable donations overall, and diminishes public spiritedness more generally, Rosenman argues. ${ }^{82}$

These are all compelling concerns. We have good reasons to worry about an erosion of public trust or altruistic sentiment, especially in light of the 
economic downturn, which has diminished individual largesse and heightened voters' resentment of those groups (for example, unions) that are seen as reaping undeserved concessions or social assistance.

But it is not clear that the concerns mandate a ban on FP higher education, for it is not clear that the other-regarding sentiment that is (on this line of argument anyway) preserved or enhanced where the profit motive is absent will tend toward funding of higher education, less still that it will do so with the innovation and flexibility that the FP sector can provide. In other words, it may be unduly optimistic to think that the public will improve the educational opportunities of historically underserved populations when it has heretofore failed to do so; the FP market for higher education would not have arisen were traditional colleges already serving all of those who were candidates for higher education as well as they could. As Martha Minow states, "The persistent failures in existing forms of social provision-in schooling [among others] ... - -supply powerful reasons for government to work with the private forces of for-profit, secular nonprofit, and religious organizations." The FP sector may provide a much-needed complement to traditional colleges and universities. It remains to be seen just what role the FP sector should play.

\section{Conclusion: Ideal Versus Non-Ideal Worlds}

In an ideally just world, every student has the opportunity and the resources to obtain a higher education-one that prepares the student both for the realities of the job market into which she will enter and for the project of selfgovernance of the polity of which she is part. We do not currently inhabit that world (if we ever did). We should not abandon hope of realizing it and, indeed, we should work toward its realization. But we cannot in the interim repudiate any and every alternative that fails to meet the standards that we would impose in this ideal world. To do so would be to fetishize purity over practicality, with the burdens of the repudiation falling disproportionately on those whom the current system already marginalizes or excludes. We should instead welcome institutions, like FP colleges, that can fill in the current gaps. ${ }^{83}$ As Kevin Carey, policy director for Education Sector, an independent think-tank in Washington, D.C., writes: "The difference between what higher learning should be in theory and what it really is in practice (and what's feasible given the current economic and funding environment) is vast. And it's in that space that new organizations are going to thrive." ${ }^{84}$ 
At the same time, we should seek to ensure that the presence of FP institutions does not entrench existing inequalities or otherwise impede progress toward a more ideal world. The general strategy flows from those theorists who view justice along two planes. The foundational plane articulates a conception of justice that we would impose in a world where we could be assured of a material surplus and where individuals recognized the equality of all. This is the ideal world. A second plane begins at the point where we acknowledge that we do not live in this ideal world, and that we need to enact temporary measures that both respond to the current non-ideal circumstances and allow us to make progress toward the ideal world.$^{85}$ In particular, these measures should "hinder the empowerment [of the disadvantaged] the least and further it the most."

FP colleges can play a part in this non-ideal world, and so we should embrace them-but only with some careful qualifications and constraints. One element of this approach requires that we secure a robust opportunity for the public will, arrived at through democratic deliberation, to guide and constrain the operation of the FP higher educational sector. This is the suggestion Jeffery Smith advances in this volume, ${ }^{87}$ and others have expressed it as well. ${ }^{88}$ But there is a prior question-namely, what the public should will on this score. The concerns about FP higher education described above provide the components of a response.

Most obviously, there must be greater governmental regulation and oversight to protect against the worst abuses-fraud, deception, and exploitation. It is permissible, and even desirable, for FP colleges to target traditionally marginalized populations. But they should do so in a manner that allows the targeted populations to arrive at a robustly informed decision about the benefits and costs of the education on offer, and without imposing undue pressure to consent. ${ }^{89}$

We might also seek to ensure that FP colleges do good by their students even as they try to do well by their shareholders. To this end, we might mandate that some percentage of the school's profits be reinvested in the institution itself, or we might insist that FP colleges qualify for an accreditation, retention of which would require that the college meet certain barometers of student success.

It is less clear that we could or should seek to insist that FP colleges provide (more) training for civic life. As niche institutions, FP colleges might focus on subjects having nothing to do with self-governance in a democratic polity, or they might recruit students from predominantly one social class, or 
ethnic, racial, or religious group, thereby denying their students the opportunity to mingle in a diverse environment. They could be encouraged to do otherwise, but the business model may make it unreasonable to demand that they do otherwise..$^{90}$ Thus we might have to resign ourselves to having some other forum or institution encourage and prepare citizens for civic engagement. (We could, for example, seek to improve the democratic training currently offered in K-12 institutions, or insist that at least some not-for-profit entities, like churches, tax-exempt social clubs, and so on, devote some time and resources to fulfilling this role in exchange for their tax-exempt status, and consistent with the constitutional guarantee of freedom of association.)

Concomitant with pursuing the specific measures aimed at the FP colleges themselves, we must seek to reform the background conditions that make FP colleges as attractive as they are. This is not the place to articulate a fullfledged plan, but we can identify some rough and ready ideas. First, we must find ways to make traditional colleges more accessible to underprivileged students-for example, we might enhance the amount and quality of academic guidance students at public high schools receive, so they are better informed about their options and more effectively led through the various admission processes, or we might encourage colleges and universities to maintain more flexible schedules or to promote work-study opportunities in other ways, or, again, we might offer a year of postsecondary, college preparatory education to students who have attended failing public high schools. (This last measure would be more affordable than more widespread reform of the failing public schools, and would at least allow the students who suffered through these schools an opportunity to catch up.)

More significantly, we ought to remedy the background inequalities that put at least some traditional institutions beyond the reach of those students whom the public schools have largely failed. In an ideal system, the quality of primary and secondary education would not vary anywhere near as widely as it does currently, nor would the worst providers be anywhere near as dismal as they are now. More generally, there would be far less inequality of wealth, and the quality of the schooling available to children would not depend on the resources of their parents.

In short, the background circumstances that set the stage for FP higher education are themselves deeply entrenched, and they will likely, and unfortunately, persist for too many years to come. Given these circumstances, and the possibility that FP colleges can function at least as a stopgap measure to ameliorate their effects, we ought not to insist upon a wholesale rejection of 
for-profit higher education. But we can require that FP colleges and universities operate in ways that do not worsen the unjust conditions that currently obtain; better still, we can seek to ensure that FP institutions actually help those who are disadvantaged to improve their lot. Profit making may be inimical to the ethos of higher education, and FP colleges may shortchange their students when it comes to training them for citizenship. But we do not now have the luxury to repudiate FP higher education altogether. To deny the disadvantaged student access to an FP college may well be to deny her access to any college at all, and so to consign her to the impoverished conditions she already inhabits. We should instead support a more highly regulated and constrained FP college sector, even as we seek to reform the injustices that provide the demand for FP colleges in the first place. 